\title{
Effect of cabinet tray dryer on Tomato (Lycopersicon Esculentum) slices during drying process and storage study of dehydrated tomato powder
}

\author{
Vishal Kumar $^{1}$, Sweta Singh ${ }^{1}$, B. R. Singh ${ }^{1}$, Suresh Chandra $^{1}$ and Samsher $^{1}$ \\ Department of Agricultural Engineering and Food Technology, Sardar Vallabhbhai Patel University of Agriculture \\ and Technology, Meerut 250110 (U.P.), INDIA \\ *Corresponding author. Email: vishalkumarsingh129@gmail.com
}

Received: October 27, 2015; Revised received: April 06, 2016; Accepted: July 05, 2016

\begin{abstract}
The effected dehydrated tomato (Lycopersicon Esculentum) samples determining by acidity, $\mathrm{pH}$, ascorbic acid, lycopene content and microbial growth. The highest acidity value 7.42 of untreated samples (4mm) in LDPE packaging material and 8.12 of untreated samples $(8 \mathrm{~mm})$ in aluminum foil packaging and the lowest pH value 2.05 of untreated samples $(6 \mathrm{~mm})$ in LDPE packaging material and 2.07 of untreated samples $(8 \mathrm{~mm})$ in aluminum foil package under cabinet tray dryer $\left(65^{\circ} \mathrm{C}\right)$ after 120 days. The lowest lycopene content value 50.71 of untreated samples $(6 \mathrm{~mm})$ in LDPE packaging material and 60.24 of untreated samples $(4 \mathrm{~mm})$ in aluminum foil packaging under cabinet tray dryer at $65{ }^{\circ} \mathrm{C}$ after 120 days. The lowest vitamin $\mathrm{C}$ value 8.54 of untreated samples (4mm) in LDPE packaging and 9.50 of untreated samples $(6 \mathrm{~mm})$ in aluminum foil packaging under cabinet tray dryer after 120 days. We can see that microbial growth not detect in the starting 30 days but after one month we can easily see microbial growth. When considering growth rates of microbial pathogens, in addition to temperature, time is a critical consideration. Food producers or manufacturers address the concept of time as it relates to microbial growth when a product's shelf life is determined. The highest microbial growth $4.55 \times 10^{2}$ of untreated samples $(6 \mathrm{~mm})$ in LDPE packaging and $4.49 \times 10^{2}$ of untreated samples $(8 \mathrm{~mm})$ in aluminum foil packaging under cabinet tray dryer after 120 days.
\end{abstract}

Keywords: Aluminum foil pouch, Cabinet tray dryer, Low density poly ethylene pouch, Preservatives

\section{INTRODUCTION}

The tomato is the fruit of th eplant Lycopersicon esculentum. (Botanically speaking, tomato is not only a fruit, but also a berry since it is formed from a single ovary.). Worldwide, tomatoes are considered an important agricultural crop and an integral part of the human diet. Although tomatoes are commonly consumed fresh, over $80 \%$ of the tomato consumption comes from processed products such as tomato juice, ketchup etc. Recent studies have indicated the potential health benefits of a diet that is rich in tomatoes. Lycopene, a major carotenoid without provitamin an activity, present in red tomatoes, is considered responsible for their beneficial effects (Shi et al., 1997; Rao et al., 1998). Vegetables and their products are of great nutritional importance since they make a significant contribution in supplying wealth of essential vitamins, minerals, antioxidants, fibers and carbohydrates that improve the quality of the diet. Many vegetables are highly seasonal in nature. They are available in plenty at a particular period of time in specific regions that many times result in market glut. Due to perishable nature, huge quantity of vegetables is spoiled within a short period. The post harvest loss in vegetables has been estimated to be about $30-40 \%$ due to inadequate post harvest handling, lack of infrastructure, process- ing, and marketing and storage facilities. The size of the fruit is influenced by the availability water to the plant. A series of quantitative and qualitative changes of the chemical composition take place during tomato fruit ripening. Organic acids, soluble sugars, amino acids, pigments and over 400 aroma compounds contribute to the taste, flavour and aroma volatile profiles of the tomatoes (Petro- Turza, 1987).

Drying is very important process applicable for agricultural and industrial products. Drying is the moisture removing process from the products. Drying reduces the bacterial growth in the products. It will helpful for preserving the products for long time. Solar drying is the oldest method of products drying. Open air solar drying method is used frequently to dry the agricultural products. But this method has some disadvantages. Therefore to avoid disadvantages it is necessary to use the other solar drying methods. Different solar drying methods are direct solar drying, indirect solar drying, and mixed mode solar drying. The device used for drying process with application of solar energy called the Solar dryer. Solar dryer are also classified with mode of air circulation (Ashish et. al., 2012).

\section{MATERIALS AND METHODS}

Studies were also carried out to evaluate the physi- 
chemical characteristics of the dried tomato slice and products. The experiments were conducted in the Process and Food Engineering Laboratory of the Department of Agricultural Engineering and Food Technology, Sardar Vallabhbhai Patel University of Agriculture and Technology, Modipuram, Meerut. Geographically, Modipuram is located in semi-arid and subtropical region at $29^{\circ} 05^{\prime} 19^{\prime \prime}$ North latitude, $77^{\circ} 41^{\prime} 50^{\prime \prime}$ East longitudes and at an altitude of 237 meters above the mean sea level.

Samples preparation with treatments: Fresh tomato was purchased from the local market Meerut. The tomatoes were cleaned to remove any dust particles attached to the surface. Then the sorted cleaned tomato was cut into the uniform thickness of $4.0 \mathrm{~mm}, 6.0 \mathrm{~mm}$ and $8.0 \mathrm{~mm}$. For the treated samples after cutting in to different sizes and slices were dipped into a solution (ml) 1:4 ratio of preservative (sodium benzoate and potassium metabisulphite). The slices were then taken out from the solution and the surface moisture was removed by blotting paper than after slices drying in cabinet tray dryer at $65{ }^{\circ} \mathrm{C}$.

\section{Experimental set-up}

Cabinet tray dryer method : The pre-treated and untreated tomato slices were dried in the cabinet tray dryer. A cabinet dryer was used for the dehydrated tomato experiments. The tomatoes slices were placed uniformly on stainless steel trays $(80 \mathrm{~cm}$ length $\times 40$ $\mathrm{cm}$ width and $1.37 \mathrm{~kg}$ weight) and experiments were conducted at $65{ }^{0} \mathrm{C}$ temperature. Weight losses (moisture content) of sample during drying process was determined, after each 1 hour interval and continued until no further weight changes were observed.

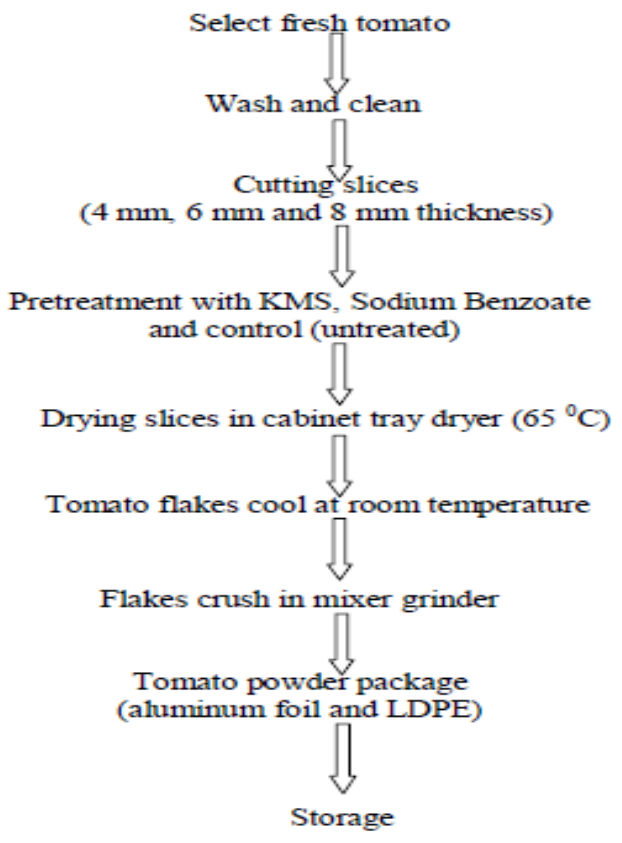

Fig 1. Process flow chart for dehydrated tomato by cabinet tray dryer.
Statistical analysis: The analysis was carried out in four replicates for all determinations. The mean and standard deviation of means were calculated. The data were analyzed by one-way analysis of variance (ANOVA). A multiple comparison procedure of the treatment means was performed by Duncan's new multiple range tests. Significance of difference of the difference was defined as $(\mathrm{P}<0.05)$.

\section{RESULTS AND DISCUSSION}

Effect on acidity: The acidity of the samples having dehydrated tomato powder with untreated and treated of tomato slices with KMS, sodium benzoate. During room temperature storage, it was observed from the Tables 1 to 2 and that acidity of all the samples was increased at $0,30,60,90$ and 120 days of storage at room temperature conditions. The highest acidity value 7.42 of untreated samples $(4 \mathrm{~mm})$ in LDPE packaging material and 8.12 of untreated samples $(8 \mathrm{~mm})$ in aluminum foil packaging under cabinet tray dryer after 120 days at room temperature conditions. We are found that superior sample of the aluminum foil pouch because this are highly protective than compression to low density polyethylene pouch. The higher acidity content prevents the growth of spoilage causing microorganisms by lowering the protein food or by the action on carbohydrate to from lactic acid. All means scores, bearing different superscripts in columns differ significantly $(\mathrm{p} \leq 0.05)$.

The higher acidity content prevent the growth of spoilage causing microorganisms by lowering the protein content of certain food or by action on carbohydrates to from lactic acid (srivastav and kumar, 2002).

Effect on Ph: The $\mathrm{pH}$ value of a food is a direct function of the free hydrogen ions present in that food. Acids present in foods release these hydrogen ions, which give acid foods their distinct sour flavor. $\mathrm{pH}$ is defined as the negative log of the hydrogen ion concentration. The $p H$, or potential of hydrogen, is the measure of acidity or alkalinity in food. The values range from 1 to 14 . Neutral is 7. Lower values are more acidic, while higher values are more alkaline. The lower the $\mathrm{pH}$ value in your food, the more acidic it is. The $\mathrm{pH}$ of various chemically pre-treated tomato samples were studied and drying rate curves as a function of drying time at constant temperature for dehydrated tomato pre -treated with KMS, sodium benzoate and control samples were plotted based on their higher dehydration efficiency. All means scores, bearing different superscripts in columns differ significantly $(\mathrm{p} \leq 0.05)$. it was observed from the Table 3 to 4 .

The lowest $\mathrm{pH}$ value 2.05 of untreated samples $(6 \mathrm{~mm})$ in LDPE packaging material and 2.07 of untreated samples $(8 \mathrm{~mm})$ in aluminum foil package under cabinet tray dryer after 120 days. This observation agrees with the work of who attributed that the decrease in 
Vishal Kumar et al. / J. Appl. \& Nat. Sci. 8 (3): 1157- 1163 (2016)

Table 1. Change in Acidity $(\mathrm{g} / 100 \mathrm{~g})$ of the samples of dehydrated tomato powder at cabinet tray dryer and storage in LDPE pouch.

\begin{tabular}{|c|c|c|c|c|c|c|c|c|c|}
\hline \multicolumn{10}{|c|}{ LDPE packaging } \\
\hline \multicolumn{10}{|c|}{ cabinet tray dryer } \\
\hline Storage & \multicolumn{3}{|c|}{ Untreated } & \multicolumn{3}{|c|}{ Treated (KMS) } & \multicolumn{3}{|c|}{ Treated (Sodium Benzoate) } \\
\hline Periods & $4 \mathrm{~mm}$ & 6mm & $8 \mathrm{~mm}$ & $4 \mathrm{~mm}$ & $6 \mathrm{~mm}$ & $8 \mathrm{~mm}$ & $4 \mathrm{~mm}$ & 6mm & $8 \mathrm{~mm}$ \\
\hline 0 & 5.80 & 5.80 & 5.80 & 5.82 & 5.82 & 5.82 & 5.81 & 5.81 & 5.81 \\
\hline 30 & 5.95 & 5.87 & 5.75 & 5.80 & 5.93 & 5.90 & 5.88 & 5.89 & 5.97 \\
\hline 60 & 6.39 & 6.26 & 6.60 & 6.12 & 6.21 & 6.35 & 6.09 & 6.15 & 6.29 \\
\hline 90 & 6.72 & 6.77 & 6.95 & 6.69 & 6.78 & 6.99 & 6.79 & 6.75 & 6.90 \\
\hline 120 & 7.42 & 7.37 & 7.45 & 7.01 & 7.12 & 7.05 & 6.99 & 7.09 & 7.12 \\
\hline
\end{tabular}

ANOVA for the effect of acidity $(\mathrm{g} / 100 \mathrm{~g})$ during storage

\begin{tabular}{|c|c|c|c|c|c|c|c|c|c|}
\hline Source & D.F. & S.S & M.S. & F-Cal & Significance & CD & $\operatorname{SE}(d)$ & SE(m) & $\mathrm{CV}$ \\
\hline Replications & 04 & 0.19 & & & & 0.231 & 0.113 & 0.080 & 2.792 \\
\hline Treatment & 08 & 12.10 & 1.51 & 47.46 & 0.000000 & & & & \\
\hline Error & 32 & 1.02 & 0.03 & & & & & & \\
\hline Total & 44 & 13.31 & & & & & & & \\
\hline
\end{tabular}

Table 2. Change in Acidity $(\mathrm{g} / 100 \mathrm{~g})$ of the samples of dehydrated tomato powder at cabinet tray dryer and store in aluminum foil pouches

\begin{tabular}{cccccccccc}
\hline \multicolumn{8}{c}{ Aluminium foil packaging } \\
\hline & \multicolumn{9}{c}{ Cabinet tray dryer } \\
\hline Storage & \multicolumn{7}{c}{ Untreated } & \multicolumn{3}{c}{ Treated (KMS) } & \multicolumn{3}{c}{ Treated (Sodium Benzoate) } \\
\cline { 2 - 11 } Periods & $\mathbf{4 m m}$ & $\mathbf{6 m m}$ & $\mathbf{8 m m}$ & $\mathbf{4 m m}$ & $\mathbf{6 m m}$ & $\mathbf{8 m m}$ & $\mathbf{4 m m}$ & $\mathbf{6 m m}$ & $\mathbf{8 m m}$ \\
\hline 0 & 5.80 & 5.80 & 5.80 & 5.82 & 5.82 & 5.82 & 5.81 & 5.81 & 5.81 \\
30 & 5.91 & 5.83 & 5.75 & 6.00 & 6.11 & 5.94 & 5.97 & 5.99 & 6.01 \\
60 & 6.47 & 6.77 & 6.93 & 6.66 & 6.87 & 6.48 & 6.19 & 6.45 & 6.67 \\
90 & 7.01 & 7.10 & 7.15 & 7.25 & 7.33 & 7.07 & 6.97 & 6.94 & 7.00 \\
120 & 7.89 & 7.88 & 7.93 & 7.41 & 7.52 & 7.22 & 7.15 & 7.21 & 7.11 \\
\hline
\end{tabular}

ANOVA for the effect of acidity $(\mathrm{g} / 100 \mathrm{~g})$ during storage

\begin{tabular}{|c|c|c|c|c|c|c|c|c|}
\hline Source & D.F. & S.S & M.S. & F-Cal & Significance & CD & $\mathrm{SE}(\mathrm{d})$ & SE(m) \\
\hline Replications & 04 & 00.11 & & & & 0.333 & 0.163 & 0.115 \\
\hline Treatment & 08 & 17.97 & 2.25 & 33.96 & 0.000000 & & & \\
\hline Error & 32 & 02.12 & 0.07 & & & & & \\
\hline Total & 44 & 20.20 & & & & & & \\
\hline
\end{tabular}

ascorbic acid content was correlated to the lowering of the $\mathrm{pH}$. The later increase in $\mathrm{pH}$ and decrease in acidity is probably due to the effect of organisms responsible for the spoilage, some of which can release basic substances into the samples. Processing of tomatoes using sun drying with cut pieces, drying of whole tomatoes, spray drying and convection drying using solar or mechanical systems has been used for many years (Baloch et al., 1997; Collins et al., 1997; Hawlader et al., 1991; Olorunda, et al., 1990; Shi et al., 1999 and Zanoni et al., 1999).

Effect on lycopene: The data for lycopene content is given in Table 5 to 6 . In the fresh tomatoes the lycopene is present in the form of all-trans isomers, which have lower bioavailability than its cis-configuration. The stability of colorants in dehydrated tomato prod- ucts during storage is affected by temperature, presence of oxygen, water activity and texture of the product. The lowest lycopene content value 50.71 of untreated samples $(6 \mathrm{~mm})$ in LDPE packaging material and 60.24 of untreated samples $(4 \mathrm{~mm})$ in aluminum foil packaging under cabinet tray dryer at $65{ }^{\circ} \mathrm{C}$ after 120 days. All means scores, bearing different superscripts in columns differ significantly $(\mathrm{p} \leq 0.05)$. (Sharma and Maguer, 1996) revealed that in the event that freeze drying and oven drying (at $25-75{ }^{\circ} \mathrm{C}$ ) were applied for tomato pulp solids, a loss in lycopene content was not significantly caused by the increase in temperature. However, freeze drying is generally seen as a very expensive preservation method; for example, freeze drying costs are 4 to 8 times higher than those of air drying (Ratti, 2001). 
Vishal Kumar et al. / J. Appl. \& Nat. Sci. 8 (3): 1157- 1163 (2016)

Table 3. Change in $\mathrm{pH}$ of the samples of dehydrated tomato powder at cabinet tray dryer and store in LDPE pouches

\begin{tabular}{cccccccccc}
\hline & \multicolumn{9}{c}{ LDPE packaging } \\
\hline & \multicolumn{3}{c}{ Cabinet tray dryer } \\
\hline Storage & \multicolumn{3}{c}{ Untreated } & \multicolumn{3}{c}{ Treated (KMS) } & \multicolumn{3}{c}{ Treated (Sodium Benzoate) } \\
\cline { 2 - 10 } Periods & $\mathbf{4 m m}$ & $\mathbf{6 m m}$ & $\mathbf{8 m m}$ & $\mathbf{4 m m}$ & $\mathbf{6 m m}$ & $\mathbf{8 m m}$ & $\mathbf{4 m m}$ & $\mathbf{6 m m}$ & $\mathbf{8 m m}$ \\
\hline 0 & 4.21 & 4.20 & 4.21 & 4.10 & 4.02 & 4.04 & 4.05 & 4.08 & 4.01 \\
30 & 3.81 & 3.77 & 3.71 & 3.65 & 3.82 & 3.85 & 3.80 & 3.79 & 3.81 \\
60 & 3.42 & 3.40 & 3.33 & 3.23 & 3.57 & 3.52 & 3.57 & 3.47 & 3.52 \\
90 & 2.94 & 2.92 & 2.81 & 2.99 & 3.00 & 2.99 & 3.00 & 3.08 & 3.11 \\
120 & 2.31 & 2.39 & 2.52 & 2.74 & 2.77 & 2.55 & 2.82 & 2.75 & 2.90 \\
\hline
\end{tabular}

ANOVA for the effect of $\mathrm{pH}$ during storage

\begin{tabular}{|c|c|c|c|c|c|c|c|c|c|}
\hline Source & D.F. & S.S & M.S. & F-Cal & Significance & CD & SE(d) & SE (m) & CV \\
\hline $\begin{array}{l}\text { Replications } \\
\text { Treatment } \\
\text { Error }\end{array}$ & $\begin{array}{l}04 \\
08 \\
32\end{array}$ & $\begin{array}{r}0.14 \\
11.80 \\
1.17\end{array}$ & $\begin{array}{l}1.47 \\
0.04\end{array}$ & 40.19 & 0.000000 & 0.248 & 0.121 & 0.086 & 5.651 \\
\hline Total & 44 & 13.12 & & & & & & & \\
\hline
\end{tabular}

Table 4. Change in $\mathrm{pH}$ of the samples of dehydrated tomato powder at cabinet tray dryer and store in aluminum foil pouches

\begin{tabular}{|c|c|c|c|c|c|c|c|c|c|}
\hline \multicolumn{10}{|c|}{ Aluminium foil packaging } \\
\hline \multicolumn{10}{|c|}{ Cabinet tray dryer } \\
\hline \multirow{2}{*}{$\begin{array}{l}\text { Storage } \\
\text { Periods }\end{array}$} & \multicolumn{3}{|c|}{ Untreated } & \multicolumn{3}{|c|}{ Treated (KMS) } & \multicolumn{3}{|c|}{ Treated (Sodium Benzoate) } \\
\hline & $4 \mathrm{~mm}$ & $6 \mathrm{~mm}$ & $8 \mathbf{m m}$ & $4 \mathrm{~mm}$ & $6 \mathrm{~mm}$ & $8 \mathbf{m m}$ & $4 \mathrm{~mm}$ & $6 \mathrm{~mm}$ & $8 \mathrm{~mm}$ \\
\hline 0 & 4.21 & 4.20 & 4.21 & 4.10 & 4.02 & 4.04 & 4.05 & 4.08 & 4.01 \\
\hline 30 & 3.82 & 3.72 & 3.69 & 3.67 & 3.80 & 3.81 & 3.83 & 3.81 & 3.79 \\
\hline 60 & 3.44 & 3.45 & 3.37 & 3.32 & 3.72 & 3.58 & 3.54 & 3.50 & 3.57 \\
\hline 90 & 3.04 & 2.88 & 2.87 & 2.82 & 3.00 & 2.94 & 3.10 & 3.07 & 3.17 \\
\hline 120 & 2.40 & 2.44 & 2.55 & 2.79 & 2.77 & 2.74 & 2.87 & 2.89 & 2.84 \\
\hline
\end{tabular}

ANOVA for the effect of $\mathrm{pH}$ during storage

\begin{tabular}{|c|c|c|c|c|c|c|c|c|c|}
\hline Source & D.F. & S.S & M.S. & F-Cal & Significance & CD & $\operatorname{SE}(d)$ & SE(m) & $\mathrm{CV}$ \\
\hline Replications & 04 & 0.10 & & & & 0.249 & 0.122 & 0.086 & 5.641 \\
\hline $\begin{array}{l}\text { Treatment } \\
\text { Error }\end{array}$ & $\begin{array}{l}08 \\
32\end{array}$ & $\begin{array}{r}11.02 \\
1.19\end{array}$ & $\begin{array}{l}1.38 \\
0.04\end{array}$ & 37.19 & 0.000000 & & & & \\
\hline Total & 44 & 12.30 & & & & & & & \\
\hline
\end{tabular}

Table 5. Change in Lycopene $(\mathrm{mg} / 100 \mathrm{gm})$ of the samples of dehydrated tomato powder at cabinet tray dryer and store in LDPE pouches

\begin{tabular}{|c|c|c|c|c|c|c|c|c|c|}
\hline \multicolumn{10}{|c|}{ LDPE packaging } \\
\hline \multicolumn{10}{|c|}{ Cabinet tray dryer } \\
\hline \multirow{2}{*}{$\begin{array}{l}\text { Storage } \\
\text { Periods }\end{array}$} & \multicolumn{3}{|c|}{ Untreated } & \multicolumn{3}{|c|}{ Treated (KMS) } & \multicolumn{3}{|c|}{ Treated (Sodium Benzoate) } \\
\hline & $4 \mathrm{~mm}$ & $6 \mathrm{~mm}$ & $8 \mathrm{~mm}$ & $4 \mathrm{~mm}$ & $6 \mathrm{~mm}$ & $8 \mathrm{~mm}$ & $4 \mathrm{~mm}$ & $6 \mathrm{~mm}$ & $8 \mathrm{~mm}$ \\
\hline 0 & 86.62 & 87.70 & 85.05 & 87.71 & 88.28 & 89.91 & 87.23 & 89.19 & 88.00 \\
\hline 30 & 80.21 & 81.44 & 83.24 & 82.88 & 84.47 & 83.67 & 80.55 & 85.76 & 81.49 \\
\hline 60 & 72.84 & 73.01 & 74.91 & 75.81 & 77.55 & 78.87 & 75.11 & 77.65 & 73.54 \\
\hline 90 & 65.44 & 66.59 & 68.59 & 69.26 & 68.46 & 71.87 & 68.77 & 69.11 & 68.95 \\
\hline 120 & 52.24 & 50.71 & 51.00 & 53.65 & 61.49 & 64.48 & 62.29 & 59.55 & 60.22 \\
\hline
\end{tabular}

ANOVA for the effect of lycopene (mg/100g) during storage

\begin{tabular}{|c|c|c|c|c|c|c|c|c|c|}
\hline Source & D.F. & S.S & M.S. & F-Cal & Significance & CD & $\operatorname{SE}(d)$ & $\mathrm{SE}(\mathrm{m})$ & $\mathrm{CV}$ \\
\hline Replications & 04 & 109.98 & & & & 4.941 & 2.415 & 1.7075 & 5.136 \\
\hline Treatment & 08 & 4924.13 & 615.52 & 42.22 & 0.000000 & & & & \\
\hline Error & 32 & 466.48 & 14.58 & & & & & & \\
\hline Total & 44 & 5500.59 & & & & & & & \\
\hline
\end{tabular}


Table 6. Change in Lycopene (mg/100gm) of the samples of dehydrated tomato powder at cabinet tray dryer and store in aluminum foil pouches

\begin{tabular}{|c|c|c|c|c|c|c|c|c|c|}
\hline \multicolumn{10}{|c|}{ Aluminium foil packaging } \\
\hline \multicolumn{10}{|c|}{ Cabinet tray dryer } \\
\hline \multirow{2}{*}{$\begin{array}{l}\text { Storage } \\
\text { Periods }\end{array}$} & \multicolumn{3}{|c|}{ Untreated } & \multicolumn{3}{|c|}{ Treated (KMS) } & \multicolumn{3}{|c|}{ Treated (Sodium Benzoate) } \\
\hline & $4 \mathrm{~mm}$ & $6 \mathrm{~mm}$ & $8 \mathrm{~mm}$ & $4 \mathrm{~mm}$ & $6 \mathrm{~mm}$ & $8 \mathrm{~mm}$ & $4 \mathrm{~mm}$ & $6 \mathrm{~mm}$ & $8 \mathrm{~mm}$ \\
\hline 0 & 86.62 & 87.70 & 85.05 & 87.71 & 88.28 & 89.91 & 87.23 & 89.19 & 90.00 \\
\hline 30 & 83.21 & 82.41 & 82.14 & 85.18 & 86.97 & 87.47 & 86.75 & 85.66 & 87.19 \\
\hline 60 & 77.74 & 80.11 & 78.81 & 78.89 & 79.22 & 80.47 & 78.31 & 80.15 & 85.74 \\
\hline 90 & 73.47 & 78.39 & 74.51 & 73.86 & 72.44 & 77.17 & 72.77 & 75.71 & 80.15 \\
\hline 120 & 60.24 & 62.71 & 65.04 & 67.75 & 68.47 & 70.88 & 69.25 & 71.55 & 73.99 \\
\hline
\end{tabular}

ANOVA for the effect of lycopene $(\mathrm{mg} / 100 \mathrm{~g})$ during storage

\begin{tabular}{|c|c|c|c|c|c|c|c|c|c|}
\hline Source & D.F. & S.S & M.S. & F-Cal & Significance & CD & $\operatorname{SE}(d)$ & SE(m) & $\mathbf{C V}$ \\
\hline Replications & 04 & 27.05 & & & & 5.040 & 2.463 & 1.742 & 4.914 \\
\hline Treatment & 08 & 2131.17 & 266.40 & 17.56 & 0.000000 & & & & \\
\hline Error & 32 & 485.36 & 15.17 & & & & & & \\
\hline Total & 44 & 2643.58 & & & & & & & \\
\hline
\end{tabular}

Table7. Change in ascorbic acid $(\mathrm{mg} / 100 \mathrm{~g})$ of the samples of dehydrated tomato powder at cabinet tray dryer and store in LDPE pouches

\begin{tabular}{|c|c|c|c|c|c|c|c|c|c|}
\hline \multicolumn{10}{|c|}{ LDPE packaging } \\
\hline \multicolumn{10}{|c|}{ Cabinet tray dryer } \\
\hline \multirow{2}{*}{$\begin{array}{l}\text { Storage } \\
\text { Periods }\end{array}$} & \multicolumn{3}{|c|}{ Untreated } & \multicolumn{3}{|c|}{ Treated (KMS) } & \multicolumn{3}{|c|}{ Treated (Sodium Benzoate) } \\
\hline & 4mm & 6mm & 8mm & $4 \mathrm{~mm}$ & 6mm & 8mm & 4mm & 6mm & 8mm \\
\hline 0 & 35.12 & 34.00 & 35.10 & 34.12 & 34.14 & 34.13 & 35.00 & 35.10 & 35.15 \\
\hline 30 & 27.44 & 30.87 & 31.11 & 29.56 & 30.02 & 30.33 & 31.25 & 30.54 & 29.90 \\
\hline 60 & 21.49 & 24.51 & 26.66 & 23.38 & 25.25 & 26.69 & 26.00 & 27.54 & 25.52 \\
\hline 90 & 16.47 & 19.01 & 19.46 & 18.71 & 17.62 & 18.54 & 19.87 & 17.36 & 18.59 \\
\hline 120 & 08.54 & 09.01 & 10.25 & 13.00 & 14.54 & 14.01 & 15.09 & 14.99 & 14.00 \\
\hline
\end{tabular}

ANOVA for the effect of ascorbic acid $(\mathrm{mg} / 100 \mathrm{~g})$ during storage

\begin{tabular}{|c|c|c|c|c|c|c|c|c|c|}
\hline Source & D.F. & S.S & M.S. & F-Cal & Significance & CD & $\operatorname{SE}(d)$ & SE(m) & $\mathrm{CV}$ \\
\hline Replications & 04 & 63.86 & & & & 3.445 & 1.684 & 1.191 & 11.001 \\
\hline Treatment & 08 & 2634.16 & 329.27 & 46.46 & 0.000000 & & & & \\
\hline Error & 32 & 226.81 & 7.09 & & & & & & \\
\hline Total & 44 & 2924.83 & & & & & & & \\
\hline
\end{tabular}

Effect on ascorbic acid: The data for ascorbic acid (Vitamin- C) is given in Table 7 to 8 , which shows that for all experiments. The lowest vitamin $\mathrm{C}$ value 8.54 of untreated samples $(4 \mathrm{~mm})$ in LDPE packaging and 9.50 of untreated samples $(6 \mathrm{~mm})$ in aluminum foil packaging under cabinet tray dryer after 120 days. The vitamin-C basically include in the dehydrated tomato powder but vitamin-C decrease in drying process because in cabinet tray dryer directly hot air to tomato slices and second main region of ascorbic acid degradation, during storage periods might be due to oxidation or irreversible conversion of L-ascorbic acid in to dehydration process ascorbic acid in the presence of enzyme ascorbic acid oxidase (ascorbinase) caused by trapped or residual oxygen in the storage conditions. All means scores, bearing different superscripts in col- umns differ significantly $(\mathrm{p} \leq 0.05)$. The observed that the ascorbic acid was very sensitive to oxidative heat damages as the reduction was significant in cabinet tray dryer, green house type solar dryer, foam mat drying and freeze drying methods. This is confirmed with the result reported by (Giovanelli et al., 2002) that the reduction in ascorbic acid content was mainly due to the temperature, exposure to direct heat on tomato slices by cabinet tray dryer and directly sun light effect on the samples of tomato slices in absence of air.

Effect on microbial growth: The microbial load of the tomato powder during storage of 120 days are shown in Table 9 to 10 it were analyzed to see the effect of microbial growth of the samples of different tomato slices thickness $(4 \mathrm{~mm}, 6 \mathrm{~mm}$ and $8 \mathrm{~mm})$ powder packed and storage at room temperature. We can see 
Vishal Kumar et al. / J. Appl. \& Nat. Sci. 8 (3): 1157- 1163 (2016)

Table 8. Change in ascorbic acid $(\mathrm{mg} / 100 \mathrm{~g})$ of the samples of dehydrated tomato powder at cabinet tray dryer and store in aluminum foil pouches

\begin{tabular}{|c|c|c|c|c|c|c|c|c|c|}
\hline \multicolumn{10}{|c|}{ Aluminium foil packaging } \\
\hline \multicolumn{10}{|c|}{ Cabinet tray dryer } \\
\hline \multirow{2}{*}{$\begin{array}{l}\text { Storage } \\
\text { Periods } \\
\end{array}$} & \multicolumn{3}{|c|}{ Untreated } & \multicolumn{3}{|c|}{ Treated (KMS) } & \multicolumn{3}{|c|}{ Treated (Sodium Benzoate) } \\
\hline & $4 \mathrm{~mm}$ & $6 \mathrm{~mm}$ & $\mathbf{8 m m}$ & $4 \mathrm{~mm}$ & $6 \mathrm{~mm}$ & $\mathbf{8 m m}$ & $4 \mathrm{~mm}$ & $6 \mathrm{~mm}$ & $8 \mathrm{~mm}$ \\
\hline 0 & 35.12 & 34.00 & 35.10 & 34.12 & 34.14 & 34.13 & 35.00 & 35.10 & 35.15 \\
\hline 30 & 27.40 & 31.89 & 31.87 & 29.00 & 30.02 & 29.39 & 31.89 & 28.54 & 30.90 \\
\hline 60 & 22.99 & 23.01 & 27.68 & 25.19 & 24.22 & 27.99 & 26.86 & 25.55 & 26.20 \\
\hline 90 & 16.40 & 18.11 & 19.00 & 17.70 & 18.52 & 17.00 & 17.02 & 18.96 & 18.50 \\
\hline 120 & 09.55 & 09.50 & 10.75 & 13.55 & 15.54 & 14.58 & 15.72 & 13.00 & 14.45 \\
\hline
\end{tabular}

ANOVA for the effect of ascorbic acid $(\mathrm{mg} / 100 \mathrm{~g})$ during storage

\begin{tabular}{|c|c|c|c|c|c|c|c|c|}
\hline Source & D.F. & S.S & M.S. & F-Cal & Significance & CD & $\mathrm{SE}(\mathrm{d})$ & $\mathrm{SE}(\mathrm{m})$ \\
\hline $\begin{array}{l}\text { Replications } \\
\text { Treatment } \\
\text { Error }\end{array}$ & $\begin{array}{l}04 \\
08 \\
32\end{array}$ & $\begin{array}{c}73.33 \\
2627.54 \\
210.32\end{array}$ & $\begin{array}{r}328.44 \\
6.57\end{array}$ & 49.97 & 0.000000 & 3.318 & 1.621 & 1.47 \\
\hline Total & 44 & 2911.19 & & & & & & \\
\hline
\end{tabular}

Table 9. Change in microbial growth $(\mathrm{cfu} / \mathrm{ml})$ of the samples of dehydrated tomato powder at cabinet tray dryer and store in LDPE pouches

\begin{tabular}{|c|c|c|c|c|c|c|c|c|c|}
\hline \multicolumn{10}{|c|}{ LDPE packaging } \\
\hline \multicolumn{10}{|c|}{ Cabinet tray dryer } \\
\hline \multirow{2}{*}{$\begin{array}{l}\text { Storage } \\
\text { Periods }\end{array}$} & \multicolumn{3}{|c|}{ Untreated } & \multicolumn{3}{|c|}{ Treated (KMS) } & \multicolumn{3}{|c|}{ Treated (Sodium Benzoate) } \\
\hline & $4 \mathrm{~mm}$ & $6 \mathrm{~mm}$ & $8 \mathrm{~mm}$ & $4 \mathrm{~mm}$ & $6 \mathrm{~mm}$ & $\mathbf{8 m m}$ & $4 \mathrm{~mm}$ & $6 \mathrm{~mm}$ & $8 \mathrm{~mm}$ \\
\hline 0 & ND & ND & ND & ND & ND & ND & ND & ND & ND \\
\hline 30 & ND & ND & ND & ND & ND & ND & ND & ND & ND \\
\hline 60 & $2.26 \times 10^{2}$ & $2.38 \times 10^{2}$ & $2.50 \times 10^{2}$ & $1.78 \times 10^{2}$ & $1.82 \times 10^{2}$ & $1.85 \times 10^{2}$ & $1.80 \times 10^{2}$ & $1.82 \times 10^{2}$ & $1.90 \times 10^{2}$ \\
\hline 90 & $3.55 \times 10^{2}$ & $3.68 \times 10^{2}$ & $3.72 \times 10^{2}$ & $2.12 \times 10^{2}$ & $2.35 \times 10^{2}$ & $2.30 \times 10^{2}$ & $2.29 \times 10^{2}$ & $2.66 \times 10^{2}$ & $2.70 \times 10^{2}$ \\
\hline 120 & $4.00 \times 10^{2}$ & $4.55 \times 10^{2}$ & $4.50 \times 10^{2}$ & $3.45 \times 10^{2}$ & $3.39 \times 10^{2}$ & $3.30 \times 10^{2}$ & $3.49 \times 10^{2}$ & $3.67 \times 10^{2}$ & $3.65 \times 10^{2}$ \\
\hline
\end{tabular}

ANOVA for the effect of microbial growth $(\mathrm{cfu} / \mathrm{ml})$ during storage

\begin{tabular}{|c|c|c|c|c|c|c|c|c|c|}
\hline Source & D.F. & S.S & M.S. & F-Cal & Significance & CD & $\mathrm{SE}(\mathrm{d})$ & $\mathrm{SE}(\mathbf{m})$ & CV \\
\hline $\begin{array}{l}\text { Replications } \\
\text { Treatment } \\
\text { Error }\end{array}$ & $\begin{array}{l}02 \\
08 \\
16\end{array}$ & $\begin{array}{r}0.20 \\
19.46 \\
0.20\end{array}$ & $\begin{array}{l}2.43 \\
0.01\end{array}$ & 192.04 & 0.000000 & 0.196 & 0.092 & 0.065 & 3.922 \\
\hline Total & 26 & 19.86 & & & & & & & \\
\hline
\end{tabular}

Table 10. Change in microbial growth $(\mathrm{cfu} / \mathrm{ml})$ of the samples of dehydrated tomato powder at cabinet tray dryer and store in aluminum foil pouches

\begin{tabular}{|c|c|c|c|c|c|c|c|c|c|}
\hline \multicolumn{10}{|c|}{ Aluminium foil packaging } \\
\hline \multicolumn{10}{|c|}{ Cabinet tray dryer } \\
\hline \multirow{3}{*}{$\begin{array}{c}\text { Storage } \\
\text { Periods } \\
0\end{array}$} & \multicolumn{3}{|c|}{ Untreated } & \multicolumn{3}{|c|}{ Treated (KMS) } & \multicolumn{3}{|c|}{ Treated (Sodium Benzoate) } \\
\hline & $4 \mathrm{~mm}$ & $6 \mathrm{~mm}$ & $8 \mathrm{~mm}$ & $4 \mathrm{~mm}$ & $6 \mathrm{~mm}$ & $8 \mathrm{~mm}$ & $4 \mathrm{~mm}$ & $6 \mathrm{~mm}$ & $8 \mathrm{~mm}$ \\
\hline & ND & ND & ND & ND & ND & ND & ND & ND & ND \\
\hline 30 & ND & ND & ND & ND & ND & ND & ND & ND & ND \\
\hline 60 & $2.36 \times 10^{2}$ & $2.40 \times 10^{2}$ & $2.52 \times 10^{2}$ & $1.88 \times 10^{2}$ & $1.98 \times 10^{2}$ & $1.80 \times 10^{2}$ & $1.80 \times 10^{2}$ & $1.86 \times 10^{2}$ & $1.91 \times 10^{2}$ \\
\hline 90 & $3.70 \times 10^{2}$ & $3.60 \times 10^{2}$ & $3.66 \times 10^{2}$ & $2.42 \times 10^{2}$ & $2.59 \times 10^{2}$ & $2.52 \times 10^{2}$ & $2.49 \times 10^{2}$ & $2.57 \times 10^{2}$ & $2.76 \times 10^{2}$ \\
\hline 120 & $4.12 \times 10^{2}$ & $4.35 \times 10^{2}$ & $4.49 \times 10^{2}$ & $3.59 \times 10^{2}$ & $3.72 \times 10^{2}$ & $3.80 \times 10^{2}$ & $3.69 \times 10^{2}$ & $3.71 \times 10^{2}$ & $3.79 \times 10^{2}$ \\
\hline
\end{tabular}

ANOVA for the effect of microbial growth $(\mathrm{cfu} / \mathrm{ml})$ during storage

\begin{tabular}{llrlllllll} 
Source & D.F. & S.S & M.S. & F-Cal & Significance & CD & SE(d) & SE(m) & CV \\
\hline Replications & 02 & 0.08 & & & & 0.145 & 0.068 & 0.048 & 2.808 \\
Treatment & 08 & 19.37 & 2.42 & 349.17 & 0.000000 & & & & \\
Error & 16 & 0.11 & 0.01 & & & & & & \\
\hline Total & 26 & 19.56 & & & & & &
\end{tabular}


that microbial growth not detect in the starting 30 days but after one month we can easily see microbial growth. When considering growth rates of microbial pathogens, in addition to temperature, time is a critical consideration. Food producers or manufacturers address the concept of time as it relates to microbial growth when a product's shelf life is determined. Shelf life is the time period from when the product is produced until the time it is intended to be consumed or used. Several factors are used to determine a product's shelf life, ranging from organoleptic qualities to microbiological safety. The highest microbial growth $4.55 \times 10^{2}$ of untreated samples $(6 \mathrm{~mm})$ in LDPE packaging and $4.49 \times 10^{2}$ of untreated samples $(8 \mathrm{~mm})$ in aluminum foil packaging under cabinet tray dryer after 120 days. All microorganisms have a defined temperature range in which they grow, with a minimum, maximum, and optimum. An understanding of the interplay between time, temperature, and other intrinsic and extrinsic factors is crucial to selecting the proper storage conditions for a food product. Temperature has dramatic impact on both the generation time of an organism and its lag period. Over a defined temperature range, the growth rate of an organism is classically defined as an Arrhenius relationship (Mossel et al., 1995).

\section{Conclusion}

Storage studies carried out for periods of 4 months showed highly effectiveness of treatments during storage. While control samples were slightly dark brown color with degradation and loss of lycopene was observed in storage tomato powder at room temperature conditions. The main causes of tomato lycopene degradation during heat processing and storage are isomerisation and oxidation. All microorganisms have a defined temperature range in which they grow, with a minimum, maximum, and optimum. Over a defined temperature range, the growth rate of an organism is classically defined as an Arrhenius relationship. The main region of ascorbic acid degradation, during storage periods might be due to oxidation or irreversible conversion of L-ascorbic acid in to dehydration process ascorbic acid in the presence of enzyme ascorbic acid oxidase (ascorbinase) caused by trapped or residual oxygen in the storage conditions but cabinet dryer sample better under aluminum foil package and same conditions foam mat drying samples are not good because egg albumen effect on the quality and vitamin-C but freeze drying samples are than compare to other samples. The later increase in $\mathrm{pH}$ and decrease in acidity is probably due to the effect of organisms responsible for the spoilage, some of which can release basic substances into the samples. The higher acidity content prevents the growth of spoilage causing microorganisms by lowering the protein food or by the action on carbohydrate to from lactic acid. The aluminum foil was found to be a good packaging material to maintain the quality and tomato powder was safe for consumption up to 4 months at room temperature conditions, LDPE package was not good because these packages absorb of moisture fast than compare to aluminum foil package.

\section{REFERENCES}

Ashish, D. Chaudhari and Prof., Sanjay, P. Salve (2012). A review of solar dryer technologies. International Journal of Research in Advant Technology, 02 (02): 218-232.

Baloch, W.A. Khan, S. and Baloch, A.K. (1997). Stability of tomato powder at intermediate moisture levels. Journal of Food Science and Technology (Mysore) (submitted).

Collins, J. L.; Sidhu, H. S. and Mullins, C. A. (1997). Drying tomatoes through osmotic treatment and dehydration. Tennessee Agricultural Sci., 182: 24-27.

Giovanelli, G., and Paradiso, A .(2002). Stability of Dried and Intermediate Moisture Tomato Pulp during Storage. Journal of Agriculture Food Chemistry. 50 (25): 7277-7281.

Hawlader, M. N. A.; Uddin, M. S.; Ho, J. C. and Teng, A. B. (1991). Drying characteristics of tomatoes. J. Food Eng., 14: 259-268.

Mossel, D.A.A.; Corry, J.E.L.; Struijk, C.B. and Baird, R.M. (1995). Essentials of the microbiology of foods: a textbook for advanced studies. Chichester (England): John Wiley and Sons. $699 \mathrm{p}$.

Olorunda, A. O.; Aworh, O. C. and Onuoha, C. N. (1990). Upgrading Quality of Dried Tomato: Effects of Drying Methods, Conditions and Pre-drying Treatments. Journal of Science Food and Agriculture 52: 447-454.

Petro-Turza, M. (1987). Taste of tomato and tomato products. Food Reviews International, 2 (3): 309-351.

Rao, A. V.; Waseem, Z. and Agarwal, S. (1998). Lycopene Content of Tomatoes and Tomato Products and their Contribution to Dietary Lycopene. Food Research International 31 (10): 737-741.

Ratti, C. (2001). Hot air and freeze drying of high-value foods: A review. Journal of Food Engineering, 49 (4): 311-319.

Sharma, S. K., and Maguer, Le, M. (1996). Kinetics of lycopene degradation in tomato pulp solids under different processing and storage conditions. Food Research International, 29 (3-4): 309-315.

Shi, J.; LE Maguer, M.; Bryan, M. and Kakuda, Y. (1999). Lycopene Degradation and Isomerisation in Tomato Dehydration. Food Research International 32: 15-21.

Shi, J.; Marc Le M; Kakuda Y; Liptay A. and Niekamp, F. (1997), Lycopene degradation and isomerisation in tomato dehydration. Journal of Food Engineering, 34: 429-440, Great Britain.

Srivastava, R.P. and Kumar, S. (2002). Fruit and vegetable preservation. International Books Distributing Company. Lucknow. 98.

Zanoni, B.; Peri, C.; Nani, R. and Lavelli, V. (1999): Oxidative Heat Damage of Tomato Halves as Affected by Drying. Food Research International. 31 (5): 395- 401. 